\title{
Co-Opted Biased Social Science: 64 Years of Telling Half Truths about the Kibbutz
}

\author{
Reuven Shapira \\ The Western Galilee Academic College, Acre, Israel \\ Email:shapi_ra@gan.org.il
}

Received 9 May 2016; accepted 31 May 2016; published 3 June 2016

Copyright (C) 2016 by author and Scientific Research Publishing Inc.

This work is licensed under the Creative Commons Attribution International License (CC BY). http://creativecommons.org/licenses/by/4.0/

(c) (7) Open Access

\begin{abstract}
Critics find that social sciences tend to comply with social domination by power elites, which is often low-moral, but the debate on public expectations of social scientists often misses this. The failed kibbutz research illuminates this problem: while supposedly abiding by such expectations, a dominant functionalist scientific coalition was co-opted by privileged old guard leaders and power elites for dozens of years to the public detriment. This coalition concealed leaders' and power elites' violations of kibbutz radical principles in inter-kibbutz organizations (hereafter I-KOs) by evading their study, and created a faked image of democracy and egalitarianism that enhanced academic success but helped conceal the pernicious conservative oligarchic hegemony of life-long I-KO leaders, harming efforts to overcome it. This eventually led to the demise of the kibbutz radical system, a failure that functionalists have failed to explain. The findings support critics of conformist social sciences while pointing to their Achilles heel, i.e., fallible survey research methods that call for new measures that minimize fallibility and the likelihood of co-opting social scientists by power elites, as well as measures that will maximize chances of exposing such scientific failures.
\end{abstract}

\section{Keywords}

Biased Social Research, Functionalist Research, Academic Freedom, Co-Opted Scientists, Inter-Kibbutz Organizations

\section{Introduction}

Recently, sociologists discussed epistemological questions of their knowledge production versus their own and public expectations of this knowledge [1]-[9]. At the same time, the social sciences have been paying increasing attention to researchers' ethics and morality [10]-[17]. While much literature deals with the scientists' ethics about individual interests less is devoted to moral caring for societal interests [18]-[20]. Such caring is consi- 
dered the task of sociologists [2] [3] [21] and other social scientists, but when empirical findings contradict normative knowledge [22], and especially when research exposes concealed or camouflaged amorality of selfperpetuating leaders and politicians (e.g., [23]-[25]), it invites researchers' co-option and/or suppression, using elite powers to conceal these efforts, keeping them a dark secret that its existence is veiled [26] [27].

Critical historians of the social sciences untangled many cases of docile social scientists complicit with power-holders domination (below). The article analyzes a unique case: the benign students' intention to help a radical society led to co-optation by dysfunctional self-perpetuating low-moral oligarchic leaders (e.g., [24] [28] [29]) that greatly harmed radicalism by telling half-truths about the studied kibbutz society that enhanced leaders' detrimental rule and suppression and the brain-drain of transformational high-moral local leaders essential for radical organizations such as cooperatives [30]. Eventually, old-guard successors were conservative loyalists without critical thinking who implemented its outdated policies even worse [31], leading to a terminal crisis. Genealogical analysis exposes scientists' support of power elites' truth concealment, violating public expectations of help in solving problems in accord with kibbutz's radical principles.

Conflict sociologists alluded to imperialistic conservatism of dominant scientific coalitions [32]-[34]. Ross [35] traced the failure of American social science to realize the promise of social studies for a free society from 1865 to, 1915, while Madoo-Lengermann and Niebrugge-Brantley [36] exposed the suppression of successful critical women sociologists by sociological patriarchs who delegitimized critical sociology through "professionalization" (also: [7]). Diamond [37] found that all major US universities collaborated with the McCarthy-serving FBI and CIA, just as they served other Cold War aims [38]. Anthropologists similarly served these aims, including CIA's, 1953 Iran coup, in return for financial support [14]. Messer-Davidow [39] found that exciting, life-changing ideas of feminism were disciplined and transformed by and within academe into dry, highly abstract academic jargon unhelpful for feminism. Greenwood and Levin [40] concluded:

"Existing power structures prefer orthodox social research, not because it produces better research but because it does not interfere with existing social arrangements. The demand for social distance and objectification separates the researcher from the subject and prevents social research from becoming an instrument of social change. The dominance of these frameworks in university environments reveals that universities, in addition to being centers of learning, play an important role in replicating existing social arrangements." (p. 237)

Levin and Greenwood [40] call for the reinventing the social sciences since “... larger organizational structures and processes of universities, campus administrative structures, national and international professional societies, and national and international ranking systems currently are inimical to the development of socially meaningful theories/practices in social sciences, ...” (p. 27). Mills [21] had already similarly criticized US sociology, calling for a change:

"Avoid the fetishism of method and technique. Urge the rehabilitation of the unpretentious intellectual craftsman, and try to become such a craftsman yourself. Let every man be his own methodologist... [and] his own theorist; let theory and method again become part of the practice of a craft. Stand for the primacy of the individual scholar; stand opposed to the ascendency of research teams of technicians” (p. 246).

Boden and Epstein [1] echoed Mills [21]: Sociologists suffer a lack of truly academic freedom that "is a necessary precondition to sociological imagination that challenges and defies the status quo" (p. 476). Universities became "highly managed and controlled spaces that produce docile bodies... that limits and inhibits the imagination to such an extent that it is difficult to create socially and economically transformational knowledge" ([1] p. 480; also: [32] [42]).

One way to create transformational knowledge is by studying successful radical societies and firms [30] [43]-[47]. Such entities usually succeed due to servant transformational leadership [48] [49]. However, with success, growth, and tenure their leaders tend to become self-perpetuating conservative ineffective rulers, whose power is used to camouflage/conceal this negative change, including from themselves [23] [24] [28]. In the case of powerful national leaders of large movements who can harm the academic careers of researchers, the researchers need integrity and courage to expose the negative leadership change since by docile orthodox research that evades exposure they can better advance academic careers though ignoring members' interests in research that would help advance their radical social ideals by overcoming leaders' conservatism. Sadly, 64 years of biased kibbutz social research, from, 1947 until, 2011, untangles such an evasive case, supporting the above criti- 
que of dominant social sciences and calls for remedies.

\subsection{The Article's Thesis and Research Questions}

"A partial truth is worse than a lie" goes the saying. A social scientist betrays subjects' trust if he knows that his study tells a partial truth about their society, remaining mute about major facts concerning some half of its field (e.g., [50] [51]). Rosner defined a kibbutz as "... a commune belonging to a Movement which is part of the Histadrut and the Labor Movement," [52 $]^{1}$ but none of his innumerable studies that inter alia made him head the Israeli Sociological Society was devoted to "The Movements", as the four federations of kibbutzim were called. Nor did he study any of the other 250 - 300 inter-kibbutz organizations (I-KOs for short), their 4000 - 4500 kibbutz member managers and administrators called pe'ilim (singular: pa'il) and 15 - 18,000 hired employees [47] [55] [56]. Numbers are inexact due to research avoidance (see below). For instance, Prof. Rosner headed the I-KO Kibbutz Research Institute, situated at Haifa University but staffed and financed by two Movements. Thus, he knew firsthand leaders' domination of kibbutz society for decades without standing for truly democratic reelection, enjoying privileges and violating its principles in other ways, but the Institute never studied I-KOs. ${ }^{2}$ Why did it avoid studying I-KOs and so did for some decades all kibbutz social researchers, ignoring I-KO violations of kibbutz culture's democracy and egalitarianism and perpetuating privileged power elites? Did they not feel obliged to study them and to inform kibbutz members about these violations? Worse still, the 269 kibbutzim (pl. of kibbutz) adopted a rotatzia (rotation) norm that limited office tenures to a few years to prevent detrimental oligarchic rule. Why did social scientists, aware of decades-long tenure of prime leaders and major I-KO heads, not study the failure of rotatzia to prevent such oligarchic rule by these leaderships which new generation leaders criticized from the 1950s (below)?

The article's thesis is that kibbutz leaders and their, loyalists concealed/camouflaged violations of its principles in I-KOs they headed and managed, barring public discussion of these violations, enhancing power, privileges, and intangible capitals [50] for prolonged hegemony of the kibbutz field, i.e., kibbutzim plus I-KOs. Critics of these violations and autocracy were suppressed, sidetracked, and mostly exited, while the first seminal kibbutz study that criticized a Movement's policy [55] was harshly criticized and sent to oblivion [56]. Thereafter, critical research that analyzes kibbutzim within the context of I-KOs (e.g., [57]) disappeared for dozens of years and was then suppressed or ignored, as functionalist social scientists dominated kibbutz research [45] [58]; it followed the above cited similar dominance of US and Israeli sociology, ignoring/evading I-KOs integral role in kibbutz society, an evasion that has continued ever since.

One obvious motive for this biased functionalist research was the benign belief that, in view of the kibbutz society's virtues, researchers must not help its opponents by exposing major failures; they would help its success more by explaining virtues and exposing only minor unsolved internal problems of kibbutzim that would motivate correction efforts. Studying the prime problem of I-KO practices violating kibbutz principles and privileging self-perpetuating power elites would give grist to the opponents of kibbutzim. However, this benign intention led to co-optation by kibbutz leaders and hegemony by functionalist scientific coalition which, even after the avoidance of critique became superfluous as kibbutzim overcame early crises and achieved major national successes, continued the suppression of students who criticized I-KOs' anti-kibbutz practices. This furthered I-KOs' ruinous impact on kibbutz social and cultural uniqueness, leading to the, 1980s crisis and abandonment of uniqueness. This partial-biased kibbutz research is explained by the following:

1) Researchers' co-optation by leaders and power-elites [59];

2) Functionalism and use of fallible survey research methods [2] [60]-[65];

3) Evasion/denial of contradictory findings by users of unobtrusive methods [66] such as anthropologists and historians;

4) Avoidance of cognitive dissonance and loss of face by never admitting any past mistakes by which were promoted successful academic careers;

5) Kibbutz researchers' elevated status encouraged lower morality [67];

6) Conflict sociologists surrendered to functionalists to join their dominant scientific coalition [32].

\section{The Case Study}

The case study that proves the above has five sections:

\footnotetext{
${ }^{1}$ The Histadrut was the General Union of Labor and the umbrella organization of all socialist movements controlled by the Mapai Party.

${ }^{2}$ Personal knowledge from five years of employment by the Institute [58].
} 
1) Hegemonic kibbutz research evaded I-KOs, concealing violations of democracy and egalitarianism.

2) A short history of evasion of I-KOs' anti-kibbutz practices.

3) Kibbutz, 1950s' crises encouraged minimal critique by researchers.

4) The dominant coalition co-opted kibbutz member researchers and conflict sociologists.

5) Sociologists were captives of a false kibbutz image of their own creation.

\subsection{Hegemonic Kibbutz Research Evaded I-KOs, Concealing Violations of Democracy and Egalitarianism}

The kibbutz became the most successful of all communal societies by being a radical social movement, highly involved in its surroundings by creating a large and complex system, which included hundreds of communal kibbutzim and hundreds of bureaucratic, hierarchic, and autocratic I-KOs. Kibbutz member pe'ilim as I-KO heads and elites dominated the field, enjoying power, prestige, privileges, intangible capitals and prolonged tenures, unlike kibbutz officers who were deprived of most of these advantages by egalitarianism, including the rotatzia (rotation) norm that shortened terms supposedly to prevent oligarchy but in reality enhancing it, particularly in I-KOs [68]-[75]. Thus, without studying I-KOs as an integral part of the kibbutz field, this society is incomprehensible [30] [45] [76]-[78]. No other communal society was so involved in national, social, and political struggles by a large web of I-KOs with an advantageous scale of operations [53] [54]. At most, communal societies had common spiritual leaders, maintained informal ties, and had some economic cooperation without societal involvement [79] [80].

Kibbutz societal involvement was integral to its spearheading of the much larger Zionist movement [81]. On the one hand, the kibbutz was an exceptional success, as this objective was attained, while the kibbutz became “... a highly successful enterprise by virtue of its longevity (compared to almost every other utopian movement), as well as any other criterion by which the success of social systems is judged” ([46] p. 4; also: [53] [82]-[84]). On the other hand, while kibbutzim took on the hardest missions of Zionism and were supported by non-socialist leaders who gave them many of World Zionist Organization (WZO) resources, they had only minor influence on the structuring of the Jewish community in Palestine, and then on Israeli society. Even among Zionist socialists they remained a minority, and after four decades of pioneering culminating in a leading role in winning the, 1948 War of Independence, the new State of Israel opted for capitalism, contrary to kibbutz socialist aims. The Kibbutz Meuchad (KM) and Kibbutz Artzi (KA) Movements encompassing some 80\% of kibbutzim that had hitherto a part of Palestine Jews leadership, remained outside the government, and their members, who had commanded the major victories of this war, were marginalized and ousted from the army [84].

Even more devastating were a series of political-ideological and economic crises in the, 1950s, resulting inter alia from the self-serving, self-perpetuating efforts of the two prime leaders, KM's Tabenkin and KA's Yaari, who prevented innovative involvement in coping with the new state's major problems [84]-[87]. However, leaders' low-moral self-perpetuating efforts commenced in, 1937-9 by the two urging reverence of Stalinism which contradicted kibbutz egalitarianism and Israeli democratic culture, legitimizing centralized control, autocracy, and censorship of publications ([88] [89] p. 178; [90]). The two became conservatives and suppressed young radical leaders who objected both Stalinism and conservatism [87] [91] [92] [95], policies which sidetracked the kibbutzim, helping the government ignore their unique needs. Later some innovative mid-levelers overcame this suppression in economic domains, enabling renewed success of the kibbutzim, which doubled their population from the, 1960s to the, 1980s [53] [82] [93] [94]. However, the prime problem of hegemony by conservative self-perpetuating privileged old guard continued [84] [86] [95] [96].

I-KOs, were integral to the success of kibbutz society [45] [54] but canonic research evaded their study because it would have exposed a conformist sector of a radical society whose practices violated its principles [73] [76] [78] [97]. Such exposure of anti-kibbutz practices would have ruined the radical kibbutz image; hence, leaders opposed it and researchers acquiesced: While hundreds studied kibbutzim and produced over 5000 publications, ${ }^{3}$ only five studied I-KOs rather recently, all except for me without such exposure [45] [54] [72]-[75] [98]-[100]. "The kibbutz movement” was a common phrase in Israeli discourse, but its students never studied kibbutzim and I-KOs as organs of a movement that had created a unique social field, ignoring field theory [50] [51]. I-KOs were presented as auxiliaries that did not affect kibbutz cultures, ignoring the hegemony of I-KO heads and power elites, which systematically violated kibbutz principles by prolonged tenures and privileges and

${ }^{3}$ On the Kibbutz Research Institute website: http://research.haifa.ac.il/index.php/home-page. 
subjugated weak rotational kibbutz officers [68] [70] [76]-[78] [101]. Rank and file members knew a little about these violations, but could not grasp their full scale and how they ensured hegemony of I-KO heads and senior tenured pe'ilim, nor knew how I-KO heads concealed and camouflaged this hegemony, helped by co-opted social scientists.

\subsection{A Short History of Evasion of I-KOs' Anti-Kibbutz Practices}

The first kibbutz researcher did not evade/ignore I-KOs: In, 1939-40 young Dr. Landshut, a sociologist-economist came to KM's Kibbutz Givat Brenner for 18 months of residential study that produced a seminal book [55]. It praised kibbutzim for their exceptional achievements, depicted Movements' policies and their impacts on kibbutzim, and criticized a major KM policy. Kibbutz leaders reacted angrily, totally rejecting the book and sending it to oblivion; for half a century it was ignored [56]. This reaction frightened Prof. Buber, Head of the Sociology Department at the Hebrew University, whose, 1947 Hebrew book commenced social scientists evasion of I-KOs. He wrote: “... the truly structural tasks of the new Village Communes [i.e. kibbutzim] begin with their federation, that is, their union under the same principle that operates in their internal structure. Hardly anywhere has it come to this” (Original italics, English version [81], p. 141). Buber did not explain why for twenty years, ever since inception in 1927 the Movements and other I-KOs "hardly came to" adopt kibbutz principles. He minimized his critique, seemingly to avoid the fate of Landshut's [55] book. If this adoption was "the truly structural task", he should have studied its neglect, but neither Buber nor his disciples did this; Landshut's critique of KM's policy and discussion of other I-KOs were ignored, and kibbutz leaders praised Buber's book and made it a must-read for the some 40,000 kibbutz members.

A few years later, three American anthropologists came to study kibbutzim and they all did likewise, ignoring both Landshut's book and I-KOs' anti-kibbutz practices [102]-[104]. These practices literally violated kibbutz principles before their very eyes, such as the amenities in pe'ilim's apartments, not found in almost all others, and pe'ilim's violation of collectivism by not permitting fellow members of their home kibbutz to use their idle company cars. Anthropologists tend to miss the impact of contexts [57] [105], and so did kibbutz ones, who missed that this, non-sharing was one of I-KOs' oligarchic practices, making I-KO cars a privileged status symbol of power elites known to everyone but the social scientists [73] [74]. The growing member discontent pushed kibbutzim in, 1962 to coerce I-KOs to let members use their cars. Many I-KO officials objected to this, causing frequent conflicts ([45] Ch. 16; [76] [78] [97]), but researchers ignored them and their roots in I-KOs anti-kibbutz practices.

Even more detrimental was the evasion of a major problem of prime leaders Tabenkin and Yaari remaining in power from 1927 with no competitive reelections [95] [96] [106]. Historians pointed out that Tabenkin and Yaari became autocrats who exhibited hubris from the early, 1950s ([87] p. 190; [91] [95] Ch. 3; [106] p. 745). Their deputies were pe'ilim from the 1920s-1930s, first as I-KO officials and then as Knesset (parliament) members and cabinet ministers, while other I-KO heads and officials also continued for dozens of years [45] [68] [70] [71] [75] [76] [78] [107]. Moreover, even those officials who seemingly abided by rotatzia, did not do so in reality: they circulated to other executive jobs, never returned to the ranks [108] [109] and often became irreplaceable local oligarchic patrons who nominated loyal clients to local managerial jobs and then promoted them to I-KO jobs [78] [83] [101].

Canonic research ignored these conspicuos violations of so basic a norm. Moreover, one could explain this ignoring until the vanishing of Tabenkin's and Yaari's leaderships in the early, $1970 \mathrm{~s}^{4}$ by researchers' fear that leaders would bar access to kibbutzim because, after Landshut's book, leaders probed students' research intentions carefully before allowing them entry ([56] p. 31). Following these vanishings, above cited authors criticized I-KO violations of kibbutz principles, Tabenkin's and Yaari’s autocracy and I-KO officials' self-serving privileged rule, but dominant social researchers ignored this critique as prove its evasion in their writings and as can be seen in their reference lists without referring to literature of autocracy and self-perpetuating privileged oligarchy (e.g., [23] [24] [31] [112]). Kressel's [110] [111] excellent ethnography of his native kibbutz, Netzer Sireni that exposed local oligarchs' rule was vehemently denounce by Ben-David [113] and Shepher [114] of the dominant functionalist scientific coalition (e.g., [32] Ch. 9) who did not disprove the findings, but rather discredited them and cited sociologists' findings which seemed to prove that Netzer Sireni was a rare, unrepresentative case. However, other ethnographies ([77] [101] [108] [115]) and a kibbutz cultural history [83] refuted

\footnotetext{
${ }^{4}$ Tabenkin died in, 1971, while Yaari became ill and resigned his offices in, 1973.
} 
them, exposing local oligarchic dominance under auspices of Movement leaders or I-KOs' CEOs in all kibbutzim studied, even when ethnographers refused to admit this contrary to their own data ([45] Ch. 15).

Functionalist sociologists and political scientist Lanir [116] ignored oligarchization of the kibbutz field and never referred to it because oligarchy was anathema to the kibbutz ethos and culture; hence, none of the 26 articles of the, 1983 Israeli Sociological Association's kibbutz research collection [117] mentioned oligarchic rule by privileged tenured leaders despite the above cited findings, as did also later authors of the dominant coalition [118] [119] [120]. The first coalition member to admit oligarchy was Rosolio in 1999, but only inside kibbutzim ([100] p. 29) while ignoring I-KO oligarchies which as an ex-Secretary General of the KM Movement, ex-Knesset (parliament) member, and a reader of critical, literature he surely knew but ignored them.

\subsection{Kibbutz, 1950s' Crises Encouraged Minimal Critique by Researchers}

One reason early researchers ignored oligarchic rule was the timing of their studies, 1949-1955, when kibbutzim were weakened by a series of crises, by their being sidetracked in national politics, and by financial distress that aroused bitter conflicts and mass exits. Without going into the details of these crises which caused mass attrition and devastation, suffice it to point out that taking a critical stand toward the kibbutzim in this dire state could have been perceived as a populist choice aimed at satisfying critical public opinion following the harsh critique of Prime Minister Ben-Gurion. Ben-Gurion's critique caused many kibbutzim to violate their principle of selfwork by employing poor unemployed new immigrants as hired workers. This violation of a major principle deepened the sense of crisis and enhanced attrition [45] [84].

Under pressure of this dire situation, leaders of the Ichud Movement decided to invite Hebrew University sociologists to study kibbutz social problems, hoping they would help in overcoming them. Sociologists' main mistake was not too abstracted empiricism (e.g., [42]) as their studies tried helping kibbutzim, but they framed research as inviting Ichud leaders have wanted, i.e. excluding I-KOs although the Ichud did not fund research (e.g., [121]) while already Landshut [55] pointed to I-KOs integrality and Buber [81] asserted that I-KOs' adoption of kibbutz principles was their "truly structural task". As disciples of Prof. Eisenstadt who heeded American-like conformist functionalism [34] the sociologists used only fallible survey studies [62] that enhanced blindness to the real problems kibbutzim were facing by evasion of I-KO elites' anti-kibbutz practices [68]-[70] [107] and the hired labor-operated kibbutz factories becoming oligarchic (e.g., [83] [110]). Neither I-KO heads' oligarchic hegemony and these factory oligarchies, nor the problems these caused in kibbutzim, were studied by functionalists' evasive surveys. ${ }^{5}$ Most conspicuous was the mass exit, up to $80 \%$ of members left many kibbutzim ([45] Chaps. 14-15; [122] p. 163). The brain-drain of talented, of critical thinkers and of innovators who tried to advance kibbutz high-moral principles but were suppressed by low-moral I-KO power elites, was followed by mass attrition of disenchanted others ([45] Ch. 14; [77] [110] [123]). But functionalists' surveys did not include leavers. Surveys were "disengaged from any concrete situation, ... record responses induced by the abstract stimuli of the survey situation as if they were authentic products of the habitus" ([61] p. 294). In surveys, both respondents and researchers are sensitive and reflexive to an unknown degree to various survey wordings and hence, outcome biases are unknown [65].

Overcoming survey defects requires analysis of hard data, such as statistics and fieldwork, to uncover the meaning of their findings by non-reactive measures, albeit usually seniors design the surveys without "the old-fashion... [of going] into the field, rather sending four dozen researchers there" ([6] p. 85) and then perform the final analysis and writing, which leads to fame and academic promotion. Survey researchers are divided into junior field workers who have little or no say in survey design and analyses, and senior theoreticians who perform only these functions [62]. The latter often lack "the profound intuitions gained from personal familiarity with the field" ([60] p. 3). Junior surveyors who met I-KO officials and saw how their power and privileges emanating from violation of kibbutz principles caused conflicts, member frustration and exits, could not study these problems, while seniors who were distanced from the field, hobnobbed with tenured oligarchic leaders who curbed their sociological sensibility (e.g., [4]) and followed in Buber's footsteps, never questioned I-KO anti-kibbutz practices and their impacts on kibbutzim.

These senior scholars gained academic recognition and their work was sanctioned by major international scientists, especially functionalists. Their reviewers, who were even more remote from the field and could not read its Hebrew language materials, could barely suspect that grasping humble rotational local kibbutz officers

\footnotetext{
${ }^{5}$ I witnessed it when participating in a survey study by Rosner's Kibbutz Research Institute.
} 
as the top stratum of kibbutzim as did Talmon [125] and Ben-Rafael and Yaar [124] was a terrible mistake that excluded from analysis the real highest strata of Movement leaders, cabinet ministers, Knesset (parliament) members, Zionist executives, and hundreds of other tenured I-KO executives mentioned by Ben-Rafael himself ([126] p. 141; also: [45] [78] [102]). Lacking Bourdieu's "profound intuitions gained from personal familiarity with the field" ([60] p. 3), reviewers did not suspect that kibbutz society was very different from all communal societies, and did not question its depiction as democratic and egalitarian despite privileged leaders' life-long tenures without reelection. For them kibbutz research was seemingly an alien science [127], having a mistaken picture of it based on reading and communicating with English-speaking seniors rather than communicating with Hebrew-speaking field-workers and ethnographers. When later reviewers consulted early works, they did not encounter the I-KO oligarchic strata, nor any other I-KOs' data disproving the egalitarian picture drawn by functionalists; hence, they too accepted the mistaken analyses.

\subsection{The Dominant Coalition Co-Opted Kibbutz Member-Researchers and Conflict Sociologists}

Since the early, 1960s, however, a few kibbutz members familiar with I-KOs as partners, employees or officers, became researchers, as did Rosner. Natives of a studied culture joining an outsiders' research team may help overcoming its cultural bias [128]. Why it did not happen with these kibbutz members? Why they joined evasion of kibbutz reality by functionalists? Worse still, new generation leaders criticized Movements' undemocratic and non-egalitarian practices, objected to reverence of Stalinism, and called for a leadership reshuffle. These young leaders were suppressed, sidetracked, and/or left [90]-[92], but even these events did not move students to study suppressing prime leaders and loyalist I-KO power elites.

According to Kuhn [129] the sticking to paradigms disproved by new findings is a common scientific problem. Collins ([32] Ch. 9) pointed out that a paradigm provides a discipline with an organization that is basically social, unifying members around the common enterprise of dominating a field of study. Bourdieu pointed out that "intellectuals have a much greater than average capacity to transform their spontaneous sociology, that is, their self-interested vision of the social world, into the appearance of a scientific sociology" ([64] p. 4). Kibbutz member researchers had an interest in envisioning the kibbutz as egalitarian and democratic in order to justify their life choices. Through the enhanced capacity mentioned by Bourdieu, they used the mistaken paradigm of kibbutz society, in which I-KOs were auxiliaries with no impact on kibbutz cultures, to ignore all the above cited critique pointing to the negative impact of the oligarchic rule of I-KOs on kibbutzim. Kibbutz memberresearchers turned their spontaneous egalitarian and democratic view of the kibbutz into an appearance of scientific sociology and senior sociologists rewarded them by publishing their works and promoting them to respected professorships. This status elevation encouraged lower morality [67] of ignoring the fact they were telling half-truths about their society.

Worse still, even kibbutz member sociologists who at first were not functionalists gave in to the functionalists in order to join the core set of kibbutz researchers (e.g., [127]). For example, Topel's [101] ethnography of his Kibbutz Mefalsim, guided by conflict sociologist professor Yonathan Shapiro, found three dominant old-guards who used patronage of loyalists whom they promoted to local management while using other means to gain popularity, such as giving members a lift to the city in their I-KO cars. However, as was usual among ethnographers [57] [105], he ignored the context of I-KOs which provided them with cars, prestigious city jobs, and other power resources. Then he became a researcher in the I-KO Yad Tabenkin, TKM's research institute, ${ }^{6}$ enjoyed such resources, and witnessed TKM officials enjoying them, but ignored all these in his, 1992 booklet. Worse still, he ignored the above cited critical publications of I-KOs' oligarchies and their dominance, as well as his own, 1979 work, asserting: "[A]lthough there are tendencies of power accumulation, the democratic processes and principle of rotatzia are functioning well” ([120] p. 35). Surrendering to the dominant functionalist coalition served it well: using concepts of conflict sociology he concealed its mistakes and prevented accusations of backward Eisenstadtian functionalism. In return he was promoted to head Yad Tabenkin's social research and published extensively.

Other conflict sociologists did likewise. Ben-Rafael and Yaar's [124] analysis of kibbutz stratification ignored oligarchic dominance by prime leaders and other tenured I-KO officials. For instance, no such powerful figures were included in the list of roles which defined kibbutz member status ([124] p. 83), although Ben-Rafael knew

$\overline{{ }^{6} \mathrm{KM}}$ and Ichud Movements merged in, 1980 to TKM Movement (Tnu'aa Kibbutzit Meuchedet). 
and mentioned them ([126] p. 141). Clear signs of co-optation success were Ben-Rafael's heading Yad Tabenkin's prime research project and his three books and a number of articles published by Yad Tabenkin.

\subsection{Sociologists Were Captives of a False Kibbutz Image of Their Own Creation}

In their efforts to conceal oligarchic reality, sociologists made other major mistakes which created a false kibbutz image that made them captives of their own false creations; only one example can be dealt with here (for more see my referred publications). Sociologists hailed the rotatzia norm, depicting it as an egalitarian device, but as cited I-KO power elites and managers of large kibbutz factories violated rotatzia, held jobs for decades as against kibbutz managers 1.5 - 3 year terms [45] [111] [130], while the seeming rotatzia of mid-level I-KO managers was mostly a circulation between managerial jobs without returning to the ranks [76] [109]. However, their circulation was controlled by patrons, tenured powerful I-KO heads who selected managers; in order to circulate a manager must prove docility to patrons. Thus, rotatzia enhanced the oligarchic process rather than curbing it as intended. Innovators whose successes diminished the authority of conservative I-KO heads received passing glory but were soon demoted in the name of rotatzia, sidetracked, and often left [45] [74]. Researchers did criticize the negative effects of officers rotation [131]-[133], but kibbutz students missed rotatzia's negative effects.

Sociologists joined forces with kibbutz leaders to create a false image of democracy and egalitarianism, an image that was true up to the late 1930s but then falsified by leaders' oligarchization. Rosenfeld [102] had already exposed signs of oligarchic dominance by senior pe'ilim but sociologists missed them as they were captives of their own false creation, a kibbutz that is not part of a large field dominated by oligarchic tenured I-KO officials. Thus, they could not explain prime problems stemming from I-KOs negative impact on kibbutzim, such as dwindling democracy [134], members' apathy, lack of work commitment, violations of egalitarianism, turnover, brain-drain, and more problems depicted by cited critics. The use of fallible research methods [60] [62] [63] [65] that created a false image of the kibbutz bred other mistakes, while mistaken research publications read by kibbutz members from the late, 1950s (e.g., [125] [135]) oiled oligarchization by leaving its opponents who sought egalitarianism and democracy with no independent outside proof to support their critique so that they became muted and/or left ([45] Ch. 14; [123]; e.g., [31]). As mentioned, the brain-drain of talented critics and innovators was followed by the exit of the disenchanted rank and file, encompassing up to $80 \%$ of members. Only the massive intake of young radicals who believed in the radical image of the kibbutz and high birth rates minimized crises and enabled growth [45]. However, this turnover also enhanced dominance of old guards, while in return for students' help in concealing their undemocratic rule, leaders helped their publishing efforts, which enhanced academic credentials, gained them respected professorships, and they established research institutes which were also blind to reality without any I-KO studies.

The early, 1950s crises that had justified uncritical writings overcame in the late, 1950s: As cited innovators defied old guard conservatism; they industrialized kibbutzim, reformed their agriculture by introducing profitable export crops, and established regional processing plants that enhanced efficiency [53] [82]-[84] [111], while the heavy investments required became feasible by Brum's [53] innovative financing scheme [93] [94]. Kibbutzim became prestigious after the victorious, 1967 Six Day War in which kibbutz member commanders and pilots played a major role (with considerable death toll). In the, 1960s successful kibbutzim with only $3.7 \%$ of the population held $22 \%$ of Knesset (parliament) seats and a third of cabinet ministers and the prime rationale for concealing their reality, i.e., defending a progressive society in crisis, vanished. But admitting mistakes is always hard, and in the case of kibbutz students it was much harder as their successful careers had been built on the distorted image they had created. They would have had to abandon the mistaken paradigm that excluded I-KOs, which permeated members' views of their society, as said member of Kibbutz Kochav in interview ([45] p. 57):

"The kibbutz is not, as we imagine, an isolated community. We very much belong to the outside, but since members don't want to sit and discuss our relations with the entities to which we belong, we are not coping with the problem. In order to explain it, we must recognize it but maybe we don't want to do that..."

The kibbutz image of an isolated commune enhanced social scientists success; abandoning it promised hardships, toil, and conflicts with colleagues who either believed in the false image or preferred to retain it for less than noble reasons. The cited Kochav member did not mention I-KOs as the "outside" to which his kibbutz be- 
longed, because he had only a faint idea about his kibbutz "belonging” to various I-KOs, many of which it owned indirectly through its Movement or other I-KOs [45] [53] [54]. The last time Kochav had held a discussion of this relationship was before he was born [134], but he was aware of this "outside” because he had read criticism of I-KOs in the kibbutz press from, 1975. However, he knew little else about them because academics stuck to their mistaken paradigm and I-KO officials prevented discussion of I-KO practices to conceal their privileges. For instance, a kibbutz journal published my critique of an I-KO’s practices [73]; its managers protested to my kibbutz secretariat, hence they were invited to a public discussion of my study but declined, clearly afraid that their violations of kibbutz principles would be exposed.

Since, 1974, after most powerful leaders had vanished, another reason for docile research disappeared, no any leader limited access to kibbutzim [56]. However, functionalists continued; for instance, as was depicted in, 1975 two of them vehemently denounced Kressel's seminal ethnography that untangled the oligarchization of Kibbutz Netzer Sireni [110] [111]. Then Kibbutz Research Institute studied kibbutz plants but not studied oligarchization in these kibbutzim (personal knowledge [90]). Time was even riper for a change from, 1980 as a series of critical publications further disproved functionalists' rosy picture of kibbutz [68] [72] [73] [76] [97] [101] [108] [136], but the dominant coalition ignored critiques and this helped ultra-conservative, loyalists without critical thinking succeed the old guard and worsen implementation of its outdated policies in accord with Hirschman [31], such as establishing 21 new kibbutzim without proper financing, adding superfluous debts [100] which together with a new hostile governmental economic policy in, 1985 more than doubled debts yearly, and the kibbutz system collapsed [137].

Even after this collapse with mismanaged I-KOs [74] responsible for a large part of the system debts [137], while governmental help for rescuing kibbutz required abandoning their principles [137], functionalists continued to ignore I-KOs, and helped conceal the heavy burden of their inflated bureaucracies. Many kibbutzim and I-KOs declared bankruptcy and many of the latter were dissolved, but even in, 1999 when Rosolio admitted the ruinous oligarchic rule of some kibbutzim he still ignored auspices by I-KO oligarchs of kibbutz local oligarchs [74] [75] [110] [111].

Above cited historical, biographic, and culture kibbutz and I-KO studies supported the critique of functionalist research, but functionalists' circumstantial explanations for the system collapse ignored critique, avoided admitting their mistakes, and continued to evade I-KO cultures’ ruinous impact on the kibbutzim. For instance, Schwartz and Naor [138] depicted as a planned democratic change the undemocratic demutualization of Kibbutz Carmelit in the 1990s by Barak (fictitious names), a local autocratic leader who headed a large national monopoly due to previous I-KO executive jobs with a very high salary, and a clique of loyalists with lucrative I-KO jobs. They did so primarily to divert salaries into their own pockets rather than giving them to the kibbutz, but the book ignored this and other contradictions of the rosy picture of “a planned change.” Functional analysis ignored personal interests behind a decade of recurrent bitter conflicts, manager resignations, I-KOs' support of the clique, and exit of some $10 \%$ of members designated "the Pillars of Carmelit” ([138] p. 114).

Similarly functionalist is Topel's 2005 analysis of “the rise of technocrats” [139]. Large salary gaps of up to six-fold between managers and workers in demutualized kibbutzim should have stopped disregard of true stratification, but Topel's explanation of “the rise of technocrats” does not: Managers' power is depicted as stemming from credentials, rather than from highly-paid top-level jobs in demutualized bureaucratic kibbutzim and oligarchic I-KOs (e.g. [78]). He calls “technocrats” local oligarchs who rule with humble technical skills but much political acumen prolonging tenures by ties with I-KO higher-ups, ignoring the weakness of other highly technically skilled kibbutz members without these (e.g., [140]).

Likewise functionalist is the Palgi and Reinhartz's 2011 collection [141], all articles ignore critical works while Topel repeats “technocracy” thesis. Even the collection's analysis of gender inequality is functionalist (pp.73-82), referring neither to any of the above-cited critical works about kibbutzim's and I-KOs’ masculine power elites, nor to critical classics of such elites [142]. The collection index includes no reference to conflict, dominance, hegemony, self-interests, office tenure, power elites, autocracy, oligarchy, privileges or the like.

\section{Summary, Discussion, and Conclusions}

Ever since Buber's 1947 book [81] ignored Landshut's 1944 book [55] and minimized the discussion of I-KOs to two sentences that pleased kibbutz leaders, Buber-following functionalists have erred scientifically and immorally harmed its subjects' interest in comprehending and overcoming their society's problems by evading 
I-KOs’ anti-kibbutz-principles practices. The benign early minimizing critique of crisis-ridden kibbutzim habituated surrender to leaders' wish for partial biased research that would serve self-perpetuation. Functionalist students abided by leaders' framing of problems [121], missed sociological sensibility of their low-moral rule [4] and evaded critical thinkers and innovators' need for knowledge leverage to overcome it. Anthropologists ignored kibbutzim's context of oligarchic I-KOs, a disregard common in anthropology, which enhanced the dominance of a functionalist scientific coalition by missing how leaders' preaching contradicted their actions and how leaders' lack of integrity ruined the trust (e.g., [143]) on which kibbutz society was based [77] [144] [149]. Though students knew that leaders and I-KO staff violated kibbutz principles from their ties with them or due to kibbutz membership, they ignored the impact of violations on kibbutzim, the brain-drain and negative selective attrition these violations caused which pruned creative high-moral leaders essential for radical communes [28] [31] [45]. Functionalist social research ignored members' distrust of leaders, which ruined the commitment and motivation that had enabled early major achievements. Eventually, succession of dysfunctional old-guards by inept loyalists lacking critical thinking [31] joined inimical governmental policies to generate a terminal crisis of kibbutz radical communalism.

However, functionalists refused to admit their mistakes that had contributed meaningfully to this crisis, adhered to the false image of a well-functioning egalitarian democracy helped by effective I-KOs. This false image greatly helped leaders' efforts to silence critics of I-KO anti-kibbutz practices who were then muted, sidetracked, and/or left. Functionalists barred/deferred critical publications that exposed the truth and either ignored those published or vehemently vilified them, while the sticking to the false kibbutz image saved functionalists' face, defended their academic status, and spared them cognitive dissonance. However, when both power elites and dominant social scientists promulgated the rosy kibbutz image critics of oligarchic rule lacked independent support for their critique, this rule continued and empowered functionalists; they established research institutes that furthered the half truths about the kibbutz, complying with the framing desired by fund-controlling I-KO heads [121].

Researchers were co-opted by powerful leaders through the stick of threat of Landshut's book [55] fate and the carrot of helping research and publication of the I-KO-excluding paradigm. The applause for Buber's book [81] stressed leaders' desire for this paradigm, which fitted anthropologists' tendency to ignore the impact of I-KOs' context on kibbutzim. Functionalists' evasive questionnaires ignored I-KOs' anti-kibbutz practices, hence up to, 1978 they did not appear in the literature that kibbutz members have read ever since Buber's hit book [81], while I-KO power elites as well concealed violations of kibbutz principles and their self-serving nature and tried to suppress any publicity. Late critical works exposed the negative impacts of I-KOs on several kibbutz domains but not on others, and this lacuna enabled functionalists to ignore, evade, and/or deny critique. Later on some conflict sociologists gave in to functionalists and even contradicted their own findings to join the dominant scientific coalition.

Functionalists managed to retain the credibility of their findings and their academic prestige by never admitting mistakes, helped by international research cooperation ${ }^{7}$ and publishing in major international outlets whose reviewers approved erroneous works lacking "the profound intuitions gained from personal familiarity with the field” ([60] p. 3) and/or due to functionalism. Functionalists were aware of the mass exit from kibbutzim (e.g., [122] p. 163) and saw talented innovative leavers succeeding in every domain of Israeli society and abroad [123] thus testifying to a brain-drain due to conservative oligarchic rule, but they ignored it, studying neither leavers nor exit rates, since this would have exposed the negative effects of oligarchic rule, contradicting their rosecolored descriptions. The kibbutz crisis caused suffering among both leavers and those who remained, except for power elites which benefited from demutualization [45]. Functionalists were caught by surprise and remained unable to explain this colossal failure of such a successful social system.

The only excuse functionalists can use may be that they followed US sociology which dominated world sociology (and still dominates, see: [3] p. 21), while in its ranks

The original passion for social justice, economic equality, human rights, sustainable environment, political freedom or simply a better world, that drew so many of us to sociology, is channelled into the pursuit of academic credentials. Progress becomes a battery of disciplinary techniques... ([3] p. 5).

Mills’ [21] critique of sociology became a classic included in every US introductory sociology course, but in Israel even conflict sociologists ignored it (e.g., [145]) and social scientists did not allude to critics of docile so-

\footnotetext{
${ }^{7}$ I participated in one such study at the Kibbutz Research Institute.
} 
cial sciences and to fallibility of survey researches until mid-1990s [34]. Functionalists helped kibbutz power elites much as US universities did in the McCarthy era, suppressed critical students much as US patriarchal functionalists suppressed critical women sociologists by "professionalization" that delegitimized critical theory; their academic success made them oblivious to critical theories, while their high status encouraged low-morality [67]. Kibbutz movement successes in the, 1960s-1970s, due to innovators whom the old guard did not suppress as they were no threat to its supremacy [94], proved to functionalists that they were right to evade the negative effects of oligarchic I-KOs. Some historians exposed functionalists' mistakes, but as they did not use pertinent sociological theories of bureaucracy, oligarchy, power elites, and social fields, as well as leadership life cycle theory [29] and leaders' moral decline theory [23]-[25], they missed functionalists' major mistakes, sparing the latter the need to admit them. The late co-optation of some conflict sociologists and some historians by the dominant scientific coalition enlarged it and ensured its continued hegemony.

The findings support Greenwood and Levin [40], Levin and Greenwood [41], and Turner's [7] critique of current social sciences, as well as Turner's ([8] p. 479) call for science studies' colleagues "to ask the politically uncomfortable questions we find so difficult”, and Wood's [121] insisting on reflecting upon the terms by which research is framed by funders. They add proofs of the perniciousness of conformist survey research that without the sociological reflexivity proposed by Bourdieu [64] advances academic careers by submitting to power-holders' wish to tell powerless subjects whatever serves the formers' dominance. Boden and Epstein [1] explained the lack of true academic freedom by university changes, while in the kibbutz case this freedom was compromised by power-holders' control of resources and accessibility much as it was with some US anthropology [14]. Functionalists suppressed much needed critically-minded social research that would have reinvigorated a defiant imagination that could have built on radical traditions in seeking a better society [33]. Functionalist survey studies are bound to low moral biases as team seniors confined to academy's ivory towers tend to suppress the dissenting views of junior field workers who discern biases of research tools such as ignoring the low-moral practices of power elites. Remote as they are from the field, senior surveyors tend to miss, major phenomena but their views dominate; without sufficiently authoritative dissenting views research tends to, miss major social problems [18]. Worse still, while interpersonal trust helps monitor actors' ethics and morality [11], senior surveyors who avoid field-work may not create mutual trust with junior field workers who discern biases of survey tools, hence, biased research is probable.

Functionalists' survey research tends to be perniciously conformist, especially in cases of oligarchic oldguards rule ([28]. Researchers' co-optation that supports them and confines whistleblowers [146] is plausible and new measures are required to prevent it. One such measure must be the practice of seniors rather than only juniors perform preliminary field work and pilot studies, acquiring "the profound intuitions gained from personal familiarity with the field" ([60] p. 3). Wallerstein [147] proposes another measure, integration of disciplines by "historical social sciences", and the critique of kibbutz historians who exposed some of functionalists' mistakes supports this, but integration is difficult to achieve due to different academic backgrounds and research methods [148]; one should note kibbutz historians' failure to utilize classics of sociology and political science for deciphering leaders' practice changes from early high-moral radical to later conformist autocratic oligarchic. In addition, much history is written in the spirit of the leaders who shaped it. Thus, one must discern the critical historical material and integrate it with unobtrusive social research findings, and with the help of a good theory, in accord with Kurt Lewin's famous remark about its practicality, one may penetrate leaders' masks and camouflages. However, the right theory may be found in another discipline; thus, more interaction and integration among disciplines by new solutions is called for.

Biased evasive research such as that of the kibbutz should be prevented; high-moral science must serve research subjects' legitimate interest in knowing the truth about their society; hence, more research on morality of social scientists is called for [10] [15]. An additional major problem of the social sciences must also be addressed in light of the suppression of critical kibbutz researchers: early students tend to defend findings against later critical disproof, as did the dominant kibbutz scientific coalition [58]. Collins exposed the problem of such negative dominance ([32] Ch. 9), but his exposure did not change publication decision-making norms in the social sciences: Disagreement among reviewers still leads to rejection; hence, one member of a dominant coalition among reviewers can be enough to block exposure of its mistakes. A reform in this method is required to limit conservative hegemony of scientific coalitions. The natural sciences norm must be adopted: even if only one reviewer agrees with an article, it is not rejected rather reviewed by an additional reviewer, and if $\mathrm{s} / \mathrm{he}$ approves it should be published. 
An additional measure can be that whenever co-optation of researchers is plausible, since gate-keeper powerholders have a vested interest in preventing critique, researchers must publish proof that their studies are not biased by this interest or by any other, considerations such as ignoring those parts of the studied field which empower low-moral self-perpetuating power-holders.

\section{References}

[1] Boden, R. and Epstein, D. (2011) A Flat Earth Society? Imagining Academic Freedom. The Sociological Review, 59, 476-495. http://dx.doi.org/10.1111/j.1467-954X.2011.02014.x

[2] Bourdieu, P. (2004) Science of Science and Reflexivity. Polity, Cambridge (UK).

[3] Burawoy, M. (2005) For Public Sociology. American Sociological Review, 70, 4-28. http://dx.doi.org/10.1177/000312240507000102

[4] Gane, N. and Back, L. (2012) C. Wright Mills 50 Years on: The Promise and Craft of Sociology Revisited. Theory, Culture \& Society, 29, 399-421. http://dx.doi.org/10.1177/0263276412459089

[5] Levin, M. and Greenwood, D. (2011) Revitalizing Universities by Reinventing the Social Sciences. In: Denzin, N.K. and Lincoln, Y.S., Eds., Sage Handbook of Qualitative Research, Sage, Thousand Oaks (CA), $27-42$.

[6] Sterne, J. (2005) C. Wright Mills, the Bureau for Applied Social Research, and the Meaning of Critical Scholarship. Cultural Studies Critical Methodologies, 5, 65-94. http://dx.doi.org/10.1177/1532708604268210

[7] Turner, S.S. (2012) De-Intellectualizing American Sociology. Journal of Sociology, 48, 346-363. http://dx.doi.org/10.1177/1440783312458226

[8] Turner, S.S. (2012) Whatever Happened to Knowledge? Social Studies of Science, 42, 474-480. http://dx.doi.org/10.1177/0306312712436555

[9] Wood, M. (2014) Lessons from the Wire: Epistemological Reflections on the Practice of Sociological Research. The Sociological Review, 62, 742-759. http://dx.doi.org/10.1111/1467-954X.12157

[10] Abend, G. (2011) Thick Concepts and the Moral Brain. European Journal of Sociology, 52, 143-172. http://dx.doi.org/10.1017/S0003975611000051

[11] Hedgecoe, A.M. (2012) Trust and Regulatory Organizations: The Role of Local Knowledge and Facework in Research Ethics Review. Social Studies of Science, 42, 662-683. http://dx.doi.org/10.1177/0306312712446364

[12] Lavanchy, A. (2013) Dissonant Alignments: The Ethics and Politics of Researching State Institutions. Current Sociology, 61, 677-692. http://dx.doi.org/10.1177/0011392113486883

[13] Penders, B. and Nelis, A.P. (2011) Credibility Engineering in the Food Industry: Linking Science, Regulation, and Marketing in a Corporate Context. Science in Context, 24, 487-515. http://dx.doi.org/10.1017/S0269889711000202

[14] Price, D.H. (2012) Counterinsurgency and the M-VICO System. Anthropology Today, 28, 16-21. http://dx.doi.org/10.1111/j.1467-8322.2012.00850.x

[15] Sin, C.H. (2005) Seeking Informed Consent: Reflections on Research Practice. Sociology, 39, 277-294. http://dx.doi.org/10.1177/0038038505050539

[16] Sismondo, S. (2009) Ghosts in the Machine: Publication Planning in the Medical Sciences. Social Studies of Science, 39, 171-198. http://dx.doi.org/10.1177/0306312708101047

[17] Kumar, M.N. (2008) A Review of the Types of Scientific Misconduct in Biomedical Research. Journal of Academic Ethics, 6, 211-228. http://dx.doi.org/10.1007/s10805-008-9068-6

[18] Bogner, A. and Wolfgang, M. (2010) How Politics Deals with Expert Dissent: The Case of Ethics Councils. Science, Technology and Human Values, 35, 888-914. http://dx.doi.org/10.1177/0162243909357913

[19] Briggle, A. (2009) The Kass Council and the Politicization of Ethics Advice. Social Studies of Science, 39, 309-326. http://dx.doi.org/10.1177/0306312708101048

[20] Grundmann, R. (2011) Climategate and the Scientific Ethos. Science, Technology and Human Values, 38, 67-93.

[21] Mills, C.W. (1959) The Sociological Imagination. Oxford University Press, New York.

[22] Shortall, S. (2013) The Role of Subjectivity and Knowledge Power Struggles in the Formation of Public Policy. Sociology, 47, 1088-1103. http://dx.doi.org/10.1177/0038038512454950

[23] Kets de Vries, M.F.R. (1993) Leaders, Fools, and Impostors. Jossey-Bass, San Francisco.

[24] Michels, R. (1959 [1915]) Political Parties. Dover, New York.

[25] Scharfstein, B.-A. (1995) Amoral Politics. SUNY Press, Albany (NY).

[26] Goffman, E. (1959) The Presentation of Self in Everyday Life. Doubleday, New York. 
[27] Griffin, R.W. and O’Leary-Kelly, A.M. (2004) The Dark Side of Organizational Behavior. Jossey-Bass, San Francisco.

[28] Brumann, C. (2000) The Dominance of One and Its Perils: Charismatic Leadership and Branch Structures in Utopian Communes. Journal of Anthropological Research, 56, 425-451. http://dx.doi.org/10.1086/jar.56.4.3630926

[29] Hambrick, D.C. and Fukutomi, G.D.S. (1991) The Seasons of a CEO’s Tenure. Academy of Management Review, 16, 719-742.

[30] Stryjan, Y. (1989) Impossible Organizations. Greenwood, New York.

[31] Hirschman, A.O. (1970) Exit, Voice, and Loyalty. Harvard University Press, Cambridge (MA).

[32] Collins, R. (1975) Conflict Sociology. Academic, New York.

[33] Kemple, T.M. and Mawani, R. (2009) The Sociological Imagination and Its Imperial Shadows. Theory, Culture \& Society, 26, 228-249. http://dx.doi.org/10.1177/0263276409349283

[34] Ram, U. (1995) The Changing Agenda of Israeli Sociology. SUNY Press, Albany (NY).

[35] Ross, D. (1991) The Origins of American Social Science. Cambridge University Press, New York.

[36] Madoo-Lengermann, P. and Niebrugge-Brantley, J. (1998) The Women Founders: Sociology and Social Theory 18301930. Random-House, Boston.

[37] Diamond, S. (1992) Compromised Campus. Oxford University Press, New York.

[38] Chomsky, N., Nader, L., et al. Eds. (1997) The Cold War and the University. New Press, New York.

[39] Messer-Davidow, E. (2000) Disciplining Feminism. Duke University Press, Durham.

[40] Greenwood, D.J. and Levin, M. (1998) Action Research, Science, and Co-Optation of Social Research. Studies in Cultures, Organizations and Societies, 4, 237-261. http://dx.doi.org/10.1080/10245289808523514

[41] Levin, M. and Greenwood, D. (2011) Revitalizing Universities by Reinventing the Social Sciences. In: Denzin, N.K. and Lincoln, Y.S., Eds., Sage Handbook of Qualitative Research, Sage, Thousand Oaks (CA), 27-42.

[42] Gane, N. (2012) Measure, Value and the Current Crises of Sociology. The Sociological Review, 59, 151-173. http://dx.doi.org/10.1111/j.1467-954X.2012.02054.x

[43] Erdal, D. (2011) Beyond the Corporation. Bodley Head, London.

[44] Semler, R. (1993) Mavrick. Warner, New York.

[45] Shapira, R. (2008) Transforming Kibbutz Research. New World Publishing, Cleveland.

[46] Spiro, M.E. (1983) Introduction: Thirty Years of Kibbutz Research. In: Krausz, E., Ed., The Sociology of Kibbutz, Transaction, New Brunswick (NJ), 1-6.

[47] Whyte, W.F. and Whyte, K.K. (1988) Making Mondragon. ILR Press, Ithaca (NY).

[48] Burns, G.M. (1978) Leadership. Harper, New York.

[49] Sendjaya, S., Sarros, J.C. and Santora, J.C. (2008) Defining and Measuring Servant Leadership Behavior. Journal of Management Studies, 45, 402-423. http://dx.doi.org/10.1111/j.1467-6486.2007.00761.x

[50] Bourdieu, P. (1977) Outline of a Theory of Practice. Cambridge University Press, Cambridge (UK). http://dx.doi.org/10.1017/CBO9780511812507

[51] Lewin, K. (1951) The Field Theory in Social Science. Harper, New York.

[52] Rosner, M. (1991) Kibbutz. Working Paper, Kibbutz Research Institute, Haifa.

[53] Brum, A. (1986) Always Controversial. Yad Tabenkin, Ramat Efal. (In Hebrew)

[54] Niv, A. and Bar-On, D. (1992) The Dilemma of Size From a System Learning Perspective: The Case of the Kibbutz. JAI Press, Greenwich.

[55] Landshut, S. (1944) The Kvutza. Sifria Tzionit Ktana, Jerusalem. (In Hebrew)

[56] Kressel, G.M. (2000) Introduction. In: Landshut, S., The Kvutza, 2nd Edition, Yad Tabenkin, Ramat Efal, 1-33. (In Hebrew)

[57] Strathern, M. (1991) Partial Connections. Rowman and Littlefield, Savage (MD).

[58] Shapira, R. (2012) Becoming a Triple Stranger: Autoethnography of a Kibbutznik's Long Journey to Discoveries of Researchers Faults. In: Hazan, H. \& Hertzog, E., Eds., Serendipity in Anthropological Research, Ashgat, Farnham, 93-108.

[59] Selznick, P. (1949) TVA and the Grass Roots. Harper, New York.

[60] Bourdieu, P. (1988) Homo Academicus. Polity Press, Cambridge (UK).

[61] Bourdieu, P. (1990) The Logic of Practice. Polity Press, Cambridge (UK). 
[62] Platt, J. (1976) Realities of Social Research. Sussex University Press, London.

[63] Platt, J. (1986) Functionalism and the Survey: The Relation of Theory and Method. The Sociological Review, 34, 501536. http://dx.doi.org/10.1111/j.1467-954X.1986.tb00687.x

[64] Wacquant, L.J.D. (1989) Toward a Reflexive Sociology: A Workshop with Pierre Bourdieu. Sociological Theory, 7, 26-63. http://dx.doi.org/10.2307/202061

[65] Yankelovich, D. (1991) Coming to Public Judgment. Syracuse University Press, Syracuse (NY).

[66] Webb, E.J. and Campbell, D.T. (1966) Unobtrusive Measures in Social Research. Rand McNally, Chicago.

[67] Piff, P.K., Stancato, D.M., Côté, S., Mendoza-Denton, R. and Keltner, D. (2012) Higher Social Class Predicts Increased Unethical Behavior. www.pnas.org./cgi/content/1118373109

[68] Lifshitz, O. (1983) Uncontrolled Power. Hadaf Hayarok, 6 June, 18 July, 15 August. (In Hebrew)

[69] Lifshitz, O. (1985) The "Power Man” of the Western Galilee. Hadaf Hayarok, 7 May. (In Hebrew)

[70] Lifshitz, O. (1986) He Who Controls the Money-Rules. Hadaf Hayarok, 21 October. (In Hebrew)

[71] Ringel-Hofman, A. (1988) 28 Years of Singular Rule, 390 Million Shekels Debt. Yedi'ot Akhronot, 29 July. (In Hebrew)

[72] Shapira, R. (1978/9) Autonomy of Technostructure: An Inter-Kibbutz Regional Organization Case Study. The Kibbutz, 276-303. (In Hebrew)

[73] Shapira, R. (1979) Who Hold the Steering? The Regional Enterprises: A Portrait. Shdemot, 9-23. (In Hebrew)

[74] Shapira, R. (1987) Anatomy of Mismanagement. Am Oved, Tel Aviv. (In Hebrew)

[75] Shapira, R. (1990) Leadership, Rotation, and the Kibbutz Crisis. Journal of Rural Cooperation, 18, 55-66.

[76] Ron, Y. (1978) The Kibbutz Ideology—Theory and Reality. Hedim, 43, 170-189. (In Hebrew)

[77] Shapira, R. (2001) Communal Decline: The Vanishing of High-Moral Leaders and the Decay of Democratic, HighTrust Kibbutz Cultures. Sociological Inquiry, 71, 13-38. http://dx.doi.org/10.1111/j.1475-682X.2001.tb00926.x

[78] Shapira, R. (2005) Academic Capital or Scientific Progress? A Critique of Studies of Kibbutz Stratification. Journal of Anthropological Research, 61, 357-380. http://dx.doi.org/10.3998/jar.0521004.0061.304

[79] Oved, Y. (1988) Two Hundred Years of American Communes. Transaction, New Brunswick (NJ).

[80] Pitzer, D.E. (Ed.) (1997) Americas Communal Utopias. University of North Carolina Press, Chapel Hill (NC).

[81] Buber, M. (1958 [1947]) Paths in Utopia. Beacon, Boston.

[82] Barkai, H. (1977) Growth Patterns of the Kibbutz Economy. North-Holland, Amsterdam.

[83] Inbari, A. (2009) Going Home. Yediot Akhronot, Tel Aviv. (In Hebrew)

[84] Near, H., (1997) The Kibbutz Movement: A History, Vol. II, Littman Library, London.

[85] Kafkafi, E. (1988) Leadership Patterns in the KA as Exposed in the Prague Affair. Me'asef Lecheker Tnuat Havoda Hatzionit Vehasocialism, No. 18, 25-34. (In Hebrew)

[86] Kafkafi, E. (1992) Truth or Faith. Yad Izhak Ben-Zvi, Jerusalem. (In Hebrew)

[87] Kynan, O. (1988) In Our Own Image: Hashomer Hatzair and the Mass Immigration. M.A. Thesis, Jewish History Department, Tel Aviv University, Tel Aviv. (In Hebrew)

[88] Keshet, S. (1995) Spiritual Underground: The Beginning of the Kibbutz Novel. Hakibbutz Hameuchad, Tel Aviv. (In Hebrew)

[89] Porat, D. (2000) Beyond the Reaches of Our Souls. Am Oved, Tel Aviv. (In Hebrew)

[90] Shapira, R. (2016) Rethinking the Reverence of Stalinism in the Kibbutz Movement. Israel Affairs, 22, 20-44. http://dx.doi.org/10.1080/13537121.2015.1111640

[91] Beilin, Y. (1984) Sons in the Shade of Their Fathers. Revivim, Tel Aviv. (In Hebrew)

[92] Cohen, M. (2000) To Give and to Receive. Hakibbutz Hameuchad, Tel Aviv. (In Hebrew)

[93] Shalem, E. (2000) Public Funding of Collective Organizations. Yad Tabenkin, Ramat Efal. (In Hebrew)

[94] Shapira, R. (2011) Institutional Combination for Cooperative Development: How Trustful Cultures and Transformational Mid-Levelers Overcame Old Guard Conservatism. In: Blanc, J. and Colongo, D., Eds., Co-Operatives Contributions to a Plural Economy, L'Harmattan, Paris, 75-90.

[95] Halamish, A. (2013) Meir Yaari. Am Oved, Tel Aviv. (In Hebrew)

[96] Tzachor, Z. (1997) Hazan-A Life Movement. Yad Izhak Ben Zvi, Jerusalem. (In Hebrew)

[97] Adar, B. (1975) Company Car: Needs and Passions. Hashavua Bakibbutz Haartzi, 3 January and 10 January. (In He- 
brew)

[98] Avrahami, E. (1993) The Functioning of the TKM—Dilemmas and Directions for Change. Yad Tabenkin, Ramat Efal. (In Hebrew)

[99] Rosolio, D. (1975) The Regional Structure of the Kibbutz Movement. Am Oved, Tel Aviv. (In Hebrew)

[100] Rosolio, D. (1999) The System and the Crisis. Am Oved, Tel Aviv. (In Hebrew)

[101] Topel, M. (1979) To Build and to Be Built: Power Elite in an Egalitarian Society. M.A. Thesis, Sociology and Anthropology Department, Tel Aviv University, Tel Aviv. (In Hebrew)

[102] Rosenfeld, E. (1951) Social Stratification in a Classless Society. American Sociological Review, 16, 766-774. http://dx.doi.org/10.2307/2087503

[103] Spiro, M.E. (1955) Kibbutz: Venture in Utopia. Harvard University Press, Cambridge.

[104] Schwartz, R.D. (1955) Functional Alternatives to Inequality. American Sociological Review, 20, 424-430. http://dx.doi.org/10.2307/2092741

[105] Marx, E. (1985) Social-Anthropological Research and Knowing Arab Society. In: Hareven, A. Ed., To Know Neighboring People, Van Lear, Jerusalem. (In Hebrew)

[106] Kanari, B. (2003) Tabenkin in the Land of Israel. Yad Tabenkin, Ramat Efal. (In Hebrew)

[107] Arieli, E. (1986) A Stumbling Block in the Yzrael Valley Kibbutzim. Hashavua Bakibbutz Haartzi, November 14. (In Hebrew)

[108] Fadida, M. (1972) The Dynamics of Career Patterns among Political Activists in a Kibbutz. M.A. thesis, Sociology and Anthropology Department, Tel Aviv University, Tel Aviv. (In Hebrew)

[109] Helman, A. (1987) The Development of Professional Managers in the Kibbutz. Revon Lekalkala, 33, 1031-1038. (In Hebrew)

[110] Kressel, G.M. (1974) Stratification versus Equality in a Kibbutz. Cherikover, Tel Aviv. (In Hebrew)

[111] Kressel, G.M. (1983) To Each according to His Needs. Cherikover, Tel Aviv. (In Hebrew)

[112] Lenski, G. (1966) Power and Privilege. Free Press, New York.

[113] Ben-David, I. (1975) Review of “Stratification versus Equality in the Kibbutz” by Kressel, G.M., The Kibbutz, 177-178. (In Hebrew)

[114] Shepher, Y. (1975) Kibbutz Sodom and Gomorra. Social Research Quarterly, 383-388. (In Hebrew)

[115] Bowes, A.M. (1989) Kibbutz Goshen. Waveland, Prospects Heights (IL).

[116] Lanir, Y. (1990) The Kibbutz as a Political System. Yad Tabenkin, Ramat Efal. (In Hebrew)

[117] Krausz, E. Ed. (1983) The Sociology of Kibbutz. Transaction, New Brunswick (NJ).

[118] Cohen, N. and Rosner, M. (1988) The Democracy and the Kibbutz. Sifriat Poalim, Tel Aviv. (In Hebrew)

[119] Shur, S. (1987) The Study of Distributive Justice un Communal Micro Societies: The Lesson of the Kibbutz. In: Gorni, Y., et al. Eds., Communal Life, Transaction, New Brunswick (NJ), 487-491.

[120] Topel, M. (1992). The Kibbutz Society_Change and Continuity. Unit 2, Kibbutz Organization, The Open University, Tel Aviv. (In Hebrew)

[121] Wood, M. (2014) Lessons from the Wire: Epistemological Reflections on the Practice of Sociological Research. The Sociological Review, 62, 742-759. http://dx.doi.org/10.1111/1467-954X.12157

[122] Leviatan, U., Oliver, H. and Quarter, J. Eds. (1998) Crisis in the Israeli Kibbutz. Praeger, Westport.

[123] Sabar, N. (1996) Kibbutz LA. Am Oved, Tel Aviv. (In Hebrew)

[124] Ben-Rafael, E. and Yaar, E. (1992) Kibbutz Stratification. In The Kibbutz Society-Change and Continuity, Unit 10. The Open University, Tel Aviv. (In Hebrew)

[125] Talmon-Garber, Y. (1957) The Family and Job Nomination of Kibbutz Second Generation Members. Megamot, 5, 370-392. (In Hebrew)

[126] Ben-Rafael, E. (1997) Crisis and Transformation. SUNY Press, Albany (NY).

[127] Hedgecoe, A.M. (2006) Pharmacogenetics as Alien Science: Alzheimers Disease, Core Sets and Expectations. Social Studies of Science, 36, 723-752. http://dx.doi.org/10.1177/0306312706059746

[128] Schinke, R.J., Enosse, L., et al. (2010) Cultural Missteps and Ethical Considerations with Indigenous Populations: Preliminary Reflections from Northeastern Ontario, Canada. Journal of Academic Ethics, 8, 233-242. http://dx.doi.org/10.1007/s10805-010-9125-9

[129] Kuhn, T. (1962) The Structure of Scientific Revolutions. University of Chicago Press, Chicago. 
[130] Meged, H. and Sobol, O. (1970) Rotatzia of Secretaries and Economic Managers in the Ichud Kibbutzim. Seminar paper, Labor Studies Department., Tel Aviv University, Tel Aviv. (In Hebrew)

[131] Gabriel, R.A. and Savage, P.L. (1981) Crisis in Command. Himalayan, New Delhi.

[132] Segal, D.R. (1981) Leadership and Management: Organizations Theory. In: Buck, J.H. \& Korb, L.J. Eds., Military Leadership, Sage, Beverly Hills (CA), 41-69.

[133] Vald, E. (1987) The Curse of the Broken Tools. Schocken, Jerusalem. (In Hebrew)

[134] Argaman, D. (1997) The General Assembly of the Kibbutz. Yad Yaari, Givat Haviva. (In Hebrew)

[135] Rosner, M. (1960) Kibbutz Work and Worker Status in the Kibbutz. Hedim, No. 64, 84-98. (In Hebrew)

[136] Shepher, I. (1980) The Boundaries of Kibbutz. In: Marx, E., Ed., A Composite Portrait of Israel, Academic Press, London, 137-177.

[137] Krol, Y. (1989) The Economic Crisis in the Kibbutzim of TKM, 1984-1988. TKM Publication, Tel Aviv. (In Hebrew)

[138] Schwartz, M. and Naor, R. (2000) Without Breaking the Tools. Yad Tabenkin, Ramat Efal. (In Hebrew)

[139] Topel, M. (2005) The New Managers. Yad Tabenkin, Ramat Efal. (In Hebrew)

[140] Mehri, D. (2005) Notes from Toyota-Land. ILR Press, Ithaca (NY).

[141] Palgi, M. and Reinhartz, S. Eds. (2011) One Hundred Years of Kibbutz Life. Transaction, New Brunswick (NJ).

[142] Kanter, R.M. (1977) Men and Women of the Corporation. Basic Books, New York.

[143] Erhard, W., Jensen, M. C. and Zaffron, S. (2009) A New Model of Integrity: An Actionable Pathway to Trust, Productivity, and Value.

[144] Rosner, M. (1993) Organizations between Community and Market: The Case of the Kibbutz. Economic and Industrial Democracy, 14, 369-397. http://dx.doi.org/10.1177/0143831X93143006

[145] Shapiro, Y. and Ben-Eliezer, U. (1987) Elements of Sociology. Am Oved, Tel Aviv. (In Hebrew)

[146] Wenger, N.S., Korenman, S.G., Berk, R. and Liu, H. (1999) Reporting Unethical Research Behavior. Evaluation Review, 23, 553-570. http://dx.doi.org/10.1177/0193841X9902300504

[147] Wallerstein, I. (2004) The Uncertainties of Knowledge. Temple University, Philadelphia.

[148] Greenwood, A. and Bernardi, A. (2014) Understanding the Rift, the (Still) Uneasy Bedfellows of History and Organization Studies. Organization, 21, 907-932. http://dx.doi.org/10.1177/1350508413514286

[149] Shapira, R. (2015) Prevalent Concealed Ignorance of Low-Moral Careerist Managers: Contextualization by a SemiNative Multi-Site Strathernian Ethnography. Management Decision, 53, 1504-1526. http://dx.doi.org/10.1108/MD-10-2014-0620 